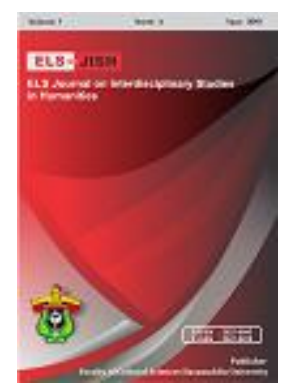

ELS-JISH

ELS Journal on Interdisciplinary Studies on Humanities

Volume 2 Issue 4, 2019

ISSN (print) : 2621-0843

ISSN (online) : 2621-0835

Homepage : http://journal.unhas.ac.id/index.php/jish

\title{
Digital Native Experience: Learning English beyond Classroom
}

\author{
Vera Nursyarah ${ }^{1}$, Nur Arifah Drajati ${ }^{2}$, Ngadiso $^{3}$ \\ 1nursyarahvera@gmail.com
}

\begin{abstract}
Extensive listening is an enjoying and meaningful listening activity which is be able to apply both in class and out of classroom. This study was to delve deeper understanding into how English studentteachers use their self-motivating strategy while using Extensive Listening in order to keep themselves motivated when facing various kinds of situation which affect their learning process. It is necessary to keep them motivated to learn independently by using various resources available on the internet such as YouTube, BBC learning English, or TED Ed to shape their habit in English listening development. Multiple participants were chosen in the study. There were 4 students of English education from one of the state University in Indonesia who are used to do Extensive Listening activity. The data were obtained from participants' autobiographies, interviews, and learners' diary. The experience of EFL students in practicing Extensive Listening was told by the participants through their learning journals and interview. This study showed that most participants use environmental control strategies to avoid disturbances from the environment, satiation control to eliminate boredom, and metacognitive control to manage their focus and concentration. Meanwhile, emotional control was not used by participants. Some of participants will try to use commitment control strategy in the future. Therefore, this study indicated that English teachers or lecturers must be aware that self-regulation skills which is used by students outside the classroom is able to support students' listening development in the foreign language English classroom.
\end{abstract}

Keywords: Autonomous Learning; Extensive Listening; Self-motivating Strategies; Narrative Inquiry

How to cite: Nursyarah, V., Drajati, N., \& Ngadiso. (2019). Digital Native Experience: Learning English beyond Classroom. ELS Journal on Interdisciplinary Studies in Humanities, 2(4), 582-594

\section{Introduction}

Krashen's input hypothesis theory stated that exposure to comprehensible input is the only way to acquire a language (Lightbown \& Spada, 1999). This theory explained that foreign language learners' success depend on the input that students get through reading and listening exposure. However, in the EFL classroom, the challenge might be faced by students is limited classroom hour, particularly for listening section. For example, Goh (2018) said that Chinese students only have 2 hours per week of listening and an approach that primarily stresses exam preparation. She argued that there is a need to find other ways of helping English learners increase their listening through independent learning outside class. Extensive listening is a choice to apply by EFL students to obtain listening input beyond the classroom.

\footnotetext{
${ }^{1,2,3}$ Universitas Sebelas Maret, Indonesia 
Renandya and Farrell (2011) argued that extensive listening provides all kinds of enjoying and meaningful listening activities that allow students to receive large input of English spoken text. By extensive listening, students will be able to acquire their listening skills naturally. Students are be able to choose autonomously whatever listening material they need to listen as much as possible. They are also able to choose a convenient place which they can use to practice Extensive listening whenever and wherever they want.

With the rapid development of technology in the 21st century, students are able to easily find various types of extensive listening material on the internet that is freely accessed anytime and anywhere. As stated by Wang \& Chen (2019), with the development of technology, language learning is not bound only in the classroom. Therefore, students must own self-regulated learning to find out independently their listening material from any source such as on the internet for their listening activities.

Dörnyei (2001) revealed that the success of independent learning, autonomous learning, and learning outside the classroom depends on the motivation possessed by students. When extensive listening activities are carried out outside the classroom, students must be able to organize themselves so that they can maintain motivation in conducting extensive listening activities even though there are no teachers who supervise and control. Dörnyei \& Ottó (1998) revealed that it is important to develop students' self-motivating strategies to organize, strengthen and maintain motivation during the learning process. Self-motivating strategies are also very closely related to learner autonomy because self-motivated learners' are students who can learn autonomously or independently (Motlhaka, 2012).

Furthermore, research on self-motivating strategy especially in listening English has been conducted by (Zeng \& Goh, 2018; Lee \& Cha, 2017). Besides that, other studies have recently found that students with high self-regulated abilities tend to have high English language achievement (Goh, 2000; Zulkepli, Fatemi, 2014; Gagen-Lanning 2015, and Khaja 2018). In addition, other studies have also found the role of technology in language learning (Kizil and Savran, 2016; Shyr and Chen, 2018; Zheng et al. 2016).

However, research exploring how English learners use self-motivating strategies in extensive listening activities is still limited. Therefore, this study tries to find out how English learners use self-motivating strategy in developing their listening skills through extensive listening activities. This study is expected to be used by English teachers to involve students in independent learning activities outside the classroom to support their English learning activities in the classroom.

\section{Method}

This study used narrative studies to examine English students' self-motivation strategies in Extensive listening activities. Barkhuizen (2014) defined narrative research as a research design in which storytelling is used as data or a means for data analysis and findings. In the study, the story which was obtained from participants used as main data.

Participants in the study were chosen based on the research objectives, so called purposive sampling. The participants of the study were multiple participants in which the participants were four undergraduate students in English Department 
range from 18-20 years in one of state university in Indonesia. In the study, the participants are two female students and two male students who used to listening various English listening material 4-6 hours a day outside the classroom as their daily activity from various resources since they were in junior high school and senior high school. The demographic Information of each participants obtained from their autobiography. Barkhuizen (2014) mentioned that the participants are the main characters in any narrative inquiry. The study will contain participants' life experiences regarding their Extensive listening activity experience which was represented as the reports.

To collect data, in-depth interview was used as the main tool for this oral narrative study. This is an example of the interview question in the study: "how do you motivate yourself when you feel bored in doing extensive listening?" .The questions in the interview were adopted from the concept of Dornyei (2005) about self-motivating strategy and Renandya and Farrrel's theory (2011) about the principle of extensive listening which was adapted from the theory of Extensive Reading Day and Bamford (2010). Semi-structured interviews were conducted in about 3 months in 6 sessions with each participant about 30-60 minutes for each session to investigate more the opinion, belief and feeling of the participants about their past experiences and current activities regarding their extensive listening activities. Afterward, the Learner diary adopted from Barkhuizen et al. (2014) was used as additional data to obtain narrative data from participants to support the findings and data in the interview.

The instruments used in the study were semi-structured interview and Learner's' diary based on the self-motivating theory from Dornyie (2005) and extensive listening by Renandya and Farrrel (2011). The total questions of interview are 15 questions consisted of fives aspects of self-motivating strategies. The interview questions were asked to the participants in other to gain answer regarding how they use self-motivating strategies in their Extensive Listening activity. The participants were also asked to write learners' diary about their extensive listening activities after each interview session. Data from interviews and participant diary journals were then analyzed using thematic analysis.

In the study, the data that have been collected were coded and analyzed using Thematic Analysis Multiple Case Studies. Barkhuizen et al. (2014) suggested that thematic analysis is data analysis which is commonly used in narrative studies involving many participants and narratives. The interpretation included the studentteachers's behavior, thoughts, and emotions within the context of Extensive Listening activity. The process of data analysis begins by listening carefully to the recording of the interview to get an interpretation and general understanding of the data. The interview transcript was then made after the researcher listened to the interview several times. The data was then read over and over to get a deeper understanding to find out the relationships between the data of each participant. Then, data was created and analyzed based on the themes.

In addition, data from diary journals were analyzed and grouped based on themes that had been made based on the results of interviews. At this stage, it is still possible for new themes to be created if there are no themes that match the data obtained from the journal diary. The themes that have been obtained are then matched with the theory used in this study. Finally, the data were presented in 
accordance with the research questions in the study.

\section{Results}

From the interview and learners' diary, the study revealed the story of four English students regarding their learning experiences when they use self-motivating strategies in their Extensive Listening Activity. This research showed how participants are able to motivate themselves when they found variety of distractors by using certain strategies to keep persistently doing extensive intensive listening activity.

\section{1. "I understand what English Natives say!" Andre's Story}

Andre is a freshman of one of States University in Indonesia. He is a second semester student in English Department. He was used to doing extensive listening to improve his English on YouTube and Internet. He liked to listen English songs randomly such as pop, electric, or country house music. He started to love listening English Songs when he was in the Senior High School. The song that firstly attracted his attention was Ed Sheeran Songs. Now, he was a big fan of Ed Sheeran, and he frequently listened to almost all of Ed Sheeran Songs. He loved to listen English Songs almost Every Day.

"I didn't only listen Ed Sheeran Songs but I also sing and read the lyrics so that I can match the lyrics with the right pronunciation. The activity helps my English Speaking a lot and also my vocabularies knowledge".

Initially, Andre accidentally watched The Expendable movie trailer when he was going to look for what movies he was planning to watch. He, then directly download that English movie and watch it. He, then feel addicted to watch another series of The Expendable Movie Film. .It was the first movie, and he started to enjoy that activity. He felt that he could not miss to watch movie in week so he made himself to watch movie every two days.

After long time doing the activity, Andre did not only feel that he only got the pleasure, but also he thought that his English skills were increasingly improved. He actually did not realized when his English skills start to improve. He only noticed that it was easier for him to catch what he listened from English native speakers when they used English in an informal daily conversation. Moreover, when he did national examination in which in the teachers never taught and provided listening material in his class, but there was a listening test in national examination, he could catch what the speakers said in the listening. He was surprised and shocked that he could understand what the speakers were saying even though he still miss some words.

The experience stick to his mind, and it was triggered him to regularly do extensive listening. He brought the habit when he got into university. In campus during waiting for the next class, he was used to listening to the music. Since it was crowded, he used earphone. Moreover, when he was at home, her mom sometimes suddenly asked him to do something, and his little brother sometimes suddenly disturbed him by putting off his earphone. Both made him lose his concentration. If it happened, he paused the English video then watched it later.

"I sometimes got furious when someone disturbed me while I focus on watching the most interesting part of movie I have been waiting before." 
He thought that the most favorite place to watch English movies was in his own bedroom because he felt that it was the most comfortable place. Moreover, he also enjoyed his extensive listening activity when he watched English movies and leaned back to the wall. Currently, He also sometimes did this activity outdoor while he was waiting his class in campus. To prevent noise which possibly distracted him, he brought an earphone. If the environment was too crowded, he postponed his activity and did it later.

"I used to do extensive listening activities in my free time. My favorite place to watch movies is my own bedroom because it is less distractions. The most comfortable position to do EL activities is when I watch a movie while leaning against the wall. I also sometimes do this activity outside the room while waiting for classes on campus. I usually bring earphone to avoid the noise that might disturb me. If I feel the environment is too crowded, I postpone my EL activities and do it later."

In the future, Andre said that he would keep continuing this hobby. He also told that he expected that he would be able to easily grasp the meaning of what he listened when watching English movie without subtitle so that he did not need to focus on reading the subtitle when he was enjoying the movie.

\section{2. "Guessing the English Lyrics": Karina's Story}

Karina is the second semester Undergraduate student in a State University in Indonesia who takes English department. He loves to listen English Songs. She does the activity when she is cleaning her room or while doing her Campus Assignments. He thinks that this activity improves her pronunciation. She now easily could recognize incorrect pronunciation when she listen other people speak English. Initially, she got difficulties in comprehending English Listening. So, she thought that this activity will improve her English listening skill.

"My house is always quiet and listening music makes me feel better."

When Karina was in senior high school, she was not permitted to bring a laptop by her teacher into the dormitory.

"When I was in junior and high school, my teachers didn't allow me to bring laptop or mobile phone during class. However, even the use of technology was limited, I can still watching movies in a break time while I did my homework in my dormitory room. So, I can keep listening English music. I usually minimize the screen and use an earphone."

Her experience staying in a dormitory was when she was in Junior High School with her friends brings her to get this hobby in the present time. Her friend was crazy of English and she loved to listen MP3 songs. Nowadays, Karina not only love to listen English Songs but also English Movies. She thinks that there are not really matter which disturb her while she does Extensive Listening activity because listening music does not require much and full attention but she sometimes feel bored when she has to watch the same music. In senior high school, Karina often find out variety of songs on planetlagu.com website.

"When I was in high school, to avoid boredom when I did EL, I selected some new English songs and download it on planetlagu.com." 
She also said that she likes to guess and memorize the English Songs lyrics because she is always curious to know the meaning of her favorite English Songs. She also likes to practice Karaoke and read the lyrics to practice her English. When I was in junior high school, I repeated the songs and write the lyrics on the paper because at that time I was not too familiar with the internet so that I didn't use google translate to know the meaning of the lyrics.

"I usually listen or watch the English Video clip song first without the lyrics, and try to guess the words and meaning from the songs, after that I saw the lyrics of the songs to make sure that the words l've guessed was matched with the lyrics. I also sing that song after I knew the lyrics with the right English vocabularies and pronunciation."

Meanwhile, listening music did not mean that it did not make her bored. When Karina was in college, she sometimes felt bored when she had to listen the same music on Spotify since on the top chart of Spotify it was the well-known songs. She simply changed and selected other English songs or skip songs that made her feel bored.

Now, after she has become a college student, she told that she also like to watch English Movie. However, sometimes, the distractors come when she watches it. She hates when someone talks to her when she is watching since he missed the plot of the story. She then has to repeat it. She also tend to watch English Movie in Movie Theatre rather than everywhere else. She feels that it is the most comfortable place which is free from any distractors so that she can be more focus.

"I'd rather watch English Movie in XXI rather than in my house. To get motivated, I watch the trailer first then choose what English movie I am going to watch. I like horror and action Movies."

In deciding what to watch, she always listen what her friends suggest. It makes her more motivated. Besides that, she told that she will subscribe music channels on Youtube, so that she will keep getting reminders when there are a lot of new song release and she will keep being 'up-to date'.

\section{3. "I got the perfect score in English Listening Skill": Farhan's Story}

Muhammad Farhan is an Undergraduate Student in the Second semester. He is an English Major Student. He watches English Movies almost every day. He started to love doing this activity since he was in junior high school. At the first, He was influenced by his brother whose hobby was watching English Movies. His friends in Senior High school also influenced his decision to choose his Extensive Listening Material. His friends liked to watch fantasy movies. Some of them like action movies, romantic dramas. Nowadays, Farhan has his own taste. He was really into watching action, comedy, fantasy, and science fiction. He easily get various kind of English movies and English songs by downloading from YouTube and Web Page.

Now, He was get used to watching English Movies and listening English Songs almost every day and everywhere.

"I usually do this activity alone in my bedroom or Campus Area. I prepare a lot of list of English songs to listen regularly. I watch English Movie every time I feel hard to fall asleep, while I am riding my motorcycle by using earphone, while I am waiting for my friends or while I am waiting for the class begin in Campus, or even while I am eating in a break time. I also 
follow an Instagram account and also browse on YouTube to watch about what I need to know and other materials that make me interested in."

Since he was in junior high school, he often did EL in his house, he often interrupted by his mom or his neighbors who asked for help and disturb him while he enjoyed watching movie. Then, that he did was pausing the video then watching the movie later in the night before he went to sleep.

Farhan felt that by doing this activity, his English ability is improved. He got new vocabularies. He also always get perfect score in listening exam. During the activity of Extensive Listening, Farhan lost his focus when there were a lot of noises from his friends. It happens since he lives in a shared house with his friends when he turned to be a college student. He then anticipated distraction by using earphone to avoid the nose.

"My friend often invites his campus friends to do their campus tasks together in our rent house and it disturbed me a lot when they made the noise."

To get rid boredom when he did extensive listening activity, he asked his friends to give the recommendations what movies he should watch or figure out on the internet about high rating movies. He also tried to fit in various music he listens with his own condition.

"When I'm lazy to do anything, the song I select is easy listening song. When I'm fully in the mood of doing something, I choose Rock Music to listen. When I am on the way to go somewhere, I tend to choose reggae music which makes me feel relaxed."

In the future, Farhan said that he will keep doing EL especially British Accent songs or movies. He said that British accent is unique. However, he thought that finding out British Accent listening material is harder than American accent songs or films.

\section{4. "I Must Watch Short English Movie Everyday": Syifa's Story}

Syifa is a student of English Department. She is in the fourth semester in Undergraduate level. For her, watching documentary movie is a must because she is really into it. She does it almost every day. She started to have this hobby when she was in Junior High School. At first, Silvia likes to watch English Movie in Trans TV Channel. In the past, Syifa who usually found some distractors from her environment. Syifa usually felt disturbed by her noisy neighbors. However, Syifa thought that when she is in her own house, she rarely finds distraction. A little distraction comes from her mom was easily controlled by pausing the video.

"When I was in high school, the distractors usually came from my neighbors and at that time I usually turned up the volume so the neighbors' voices can't be heard. I also chose to sit comfortably in order to stay concentrated because I know I can be more relaxed and focused."

After Syifa became a college students, she lived in a shared house with her friends near the campus. She had to get used to listening to the noise from other rooms. She felt uncomfortable when doing EL activities in a crowded place. What makes Syifa felt uncomfortable was when her friends talk loudly. To eliminate 
interference from others, Syifa usually closed door and used earphones during Extensive Listening activities.

"When I do EL, the things that disturb my attention were my friends in who talk too loudly because we stayed in a shared house and I usually close the door and plug my ears using earphone."

Even so, Syifa thought that the best place to do extensive listening was in her bedroom or some quiet places on campus. She also thought that the best time to do extensive listening activities was in the afternoon or evening. She also felt comfortable when she did extensive listening while she was in leaning back position or while she was eating.

Now, this habit made she feel more addicted to watch English Movie. Movie Genre she loved the most was Documentary, Fantasy, other scientific Film, or Speech from Famous Person about social or feminist. Now, she thought that her English level was higher rather than when she was in Junior or Senior High School. Currently, to keep motivated and persisted to do extensive listening, she used her mobile phone so that she was able to watch English short video everywhere. However, some distractions still appeared from her mobile phone itself.

"Phone Calls or Message Notification that suddenly pops out on my mobile phone sometimes distract my focus when I'm enjoying watch my favorite short Movie".

The destruction came not only from her surrounding but also form her mobile phone itself in which it was a device she frequently used to do extensive listening. Syifa usually interrupted by notifications messages from her social media such as Whatsapp that suddenly appear in which those notifications shifted her focus when she was watching her favorite short video. Soon she changed the mobile phone setting into silent mode and continued watching.

"I can't focus when there is a lot of noise from my mobile phone because I use my mobile phone to watch YouTube. So, I decided to change my mobile phone notification into silent mode."

Even Syifa was getting used to doing extensive listening, and she felt pleasure to do it. Syifa said that sometimes the same and repeated topics in the video made her feel bored. YouTube platform frequently provided videos which she once watched. Therefore, she usually started to search other video with different topic such as beauty vlogger

In the future, Syifa would use the similar strategies to deal with similar distractions in order to keep maintaining her motivation in practicing Extensive Listening. She said that doing Extensive Listening regularly will support her academic achievement and improve her professional development because she realizes that she will be an English teacher in the future. She said that she will search other kinds of listening material and subcribe some English Youtobe channel such as Asian boss, Rescinary 29, and DW documentary. She also said that she will try to use browse and find out the meaning of the unfamiliar words in google because she thought that book dictionary does not provide words with the appropriate meaning based on context such as slang words and other various English expressions, etc. 
Besides that, when her friends was noisy when she does Extensive listening, she would ask them not to be noise. Conversely, if the source of distractions came from strangers, she simply would move to other more silent places. To break boredom, Syifa wanted to challenge herself to watch unusual videos or movies. It was a topic which she never watch before such as video about food. The important one was that the video was in English. Moreover, learning from her experience, she was more aware how to handle a distraction especially form her mobile phone since she used it to do extensive listening. She intended to turn off the internet data on her mobile phone, and watched the videos that have been already downloaded. Offline mode would be minimized the distraction.

\section{Discussion}

The success of self-regulation in learning depends on the motivation possessed by students (Dörnyei, 2001). In other to be self-regulated, students must determine their own learning material, goals, and evaluation by themselves without teacher's supervision. In Extensive listening, students are free to choose and find their own listening material independently. This study explores how English students use selfmotivating strategies in extensive listening activity. The finding suggested that English students turn off their mobile phone to maintain their concentration, look for some variations of new material to prevent boredom, and move to a quiet place to deal with distractions from the environment.

The results showed three of the participants tend to choose a quiet place and they use headphones during Extensive Listening activities. Similarly, Rose and Harbon (2013) found that students prefer doing EL in a relax environment which to avoid distractions. Meanwhile, Zaper (2018) found that students know how to choose environment which is appropriate to avoid distractions during the learning process. Kirmizi (2014) in his research found that most of participants could easily know a comfortable place to study and also could choose a place which is far from distractions. Hence, it can be concluded that the majority of participants use the Environmental Control Strategy when they try to avoid distractors from others in EL activities. Dornyei (2001) stated that the Environmental Control Strategy used for eliminating negative environmental influences and exploiting positive environmental influences by making the environment an ally in the pursuit of a difficult goal (e.g., eliminating distractions; asking friends to help one not to allow oneself to do something). This helps students to cope with the situation in which the learning environment does not support students to learn.

In this study, two of the participants avoided things that disturbed their concentration while doing EL activities by turning off their mobile phone or changing their mobile phone settings into silent mode to prevent annoying noise. In addition, this study revealed that one of the participants usually stops the video he is watching when someone cuts him off to do something else. Alm (2013) also shows that students first stop listening and replay continuously to understand and focus their attention. Meanwhile, Lee \& Cha (2017) found that students use selective selection in which students repeat several times to understand some missing parts which are not understandable when doing Extensive Listening. Dornyei (2001) said that the Metacognitive Strategy is a strategy to maintain concentration and reduce delays. 
Meanwhile, three of participants reported that they chose music and other film genres to get rid of boredom when they felt bored while listening or watching the same genre of films in their Extensive Listening activity. In contrast, Rose and Harbon (2012) found another way which used by students to eliminate boredom by managing the time spent studying or dividing learning sessions into smaller portions, with prizes when completing each part. In another case, two other participants tried to find out what films their friends liked when they began to feel bored with the films they usually watch. In line with Alm (2013) who found that students begin watching new programs if they see their classmates enjoying them. Dornyei (2001) argues that the Satiation Control Strategy is a strategy to eliminate boredom.

Based on this study, all of the participants said that they could not be consistent in doing $E L$ in a certain time target. They also mentioned that they did not have specific goals related to academic grades by conducting Extensive Listening. They also don't even have short-term or long-term goals for doing EL activities related to their future, for example doing EL activities regularly to get high Toefl or lelts score. Goh (2002) in Alm (2013) states that managing time to maintain consistency is a big challenge for many language learners, especially if they are left to do it themselves without teacher's supervision. In contrast, Murphy (2011) and Lee \& Cha (2017) found different results. Murphy (2011) found that participants tended to use the Commitment Control Strategy to continue learning English for their personal goals in the future. (For example, going abroad or getting a higher score). Lee \& Cha (2017) also found that the purpose of students when doing EL was to be able to watch American drama without translation. Meanwhile, Kirmizi (2014) in his research found that almost half of participants can achieve their learning goals and also make shortterm and long-term goals. This study indicated that participants do not have goal commitment. According to Dornyei (2001) Commitment control strategy is a strategy used to consistently achieve goals.

Participants said that the English Songs they listened to actually healed their frustration and sad feelings. They tend to choose sad songs when they have negative feelings and watch English Language Music to entertain and help them forget their own problems. As mentioned earlier, one of the Extensive Listening Principles proposed by Day and Bamford (2010) that Extensive Listening is reward itself. However, one of participants felt unable to watch an English language film when he was feeling stressed. It indicated that this study showed that all participants did not need an Emotion Control Strategy to carry out Extensive Listening activities because they could still listen to English songs that match their emotions. In contrast to Zaper's research (2018) which shows that the Emotion Control Strategy is widely used by students after the Environmental Control strategy. Meanwhile, according to Dornyei (2001) Emotion Control Strategy is an emotional control strategy for managing disruptive emotional states or situations.

Thus, it can be concluded that in this study, the Environmental Strategy and Satiation Control are often used by participants compared to the Commitment, Emotion, and Metacognitive Control Strategies Similarly, Vujnović (2017) asserted that the Environmental Control Strategy is widely used by English learners both male andfemale participants. This study is also in line with previous studies from Safdari and Maftoon (2016) who found that students mostly use Environmental Control rather than Commitment Control which is very rarely used. Zafer (2018) also found that the 
Environmental Control strategy was the strongest aspect of the self-motivating strategy, and the strategy most rarely used was the Metacognitive Control Strategy. In this study it was also found that Metacognitive Control was more rarely used than the Environmental Control Strategy. In addition, it was also found that the Commitment and Emotion Control strategy was not used by participants.

\section{Conclusion}

The purpose of this study was to determine the self-motivating strategies undertaken by English education students by exploring how English education students apply self-motivating strategies in extensive listening activities. The findings in this study revealed that the majority of participants using environmental strategies by choosing a place far from the crowd, and also wear headset. In addition, the participant also uses satiation control by selecting various EL topics in various sources. Besides that participants ask friends for movies and songs recommendations. In addition, participants used a metacognitive strategy to avoid distractions by changing their mobile phone to turn into silent mode and choose a comfortable place which is free from distractions before they began extensive listening.

The results also revealed that students chose a variety of topics from various sources in extensive listening activities. In a formal context, the teacher can assist students in providing a variety of listening material from various sources such as YouTube channel, websites, mobile apps, and Instagram accounts that support students' extensive listening activities related to the material taught in the classroom.

In addition, the teacher can also ask students to share their extensive listening resources with their friends so that they can easily find variety of topics and sources of extensive to avoid boredom when they find the topics and sources of extensive listening which are less varied. In the study, it was found that suggestions from friends became one of the students' considerations in doing extensive listening.

From the results of the study, it was also found that students tend to imitate their family or friends in terms of extensive listening. Therefore, the teacher can be a role-model for students about how to do extensive listening activities. Institutions can also provide support in the form of training for teachers on how to teach extensive listening to their students. In addition, the institution should also provide facilities that support extensive listening activities by providing adequate infrastructure such as WiFi for internet access, listening corners, audiobooks, and sound systems.

However, in the study, researchers did not pay attention to the background achievement of the participants. Therefore, the next researcher can compare the self-motivating strategy used by students with low achievement and participants who have high achievement. Next researcher is also able to examine the participants with the different gender or level of education.

\section{References}

Alm, A. (2013). Extensive Listening 2.0 with foreign language podcast. Innovation in Language Learning and Teaching, 7, 266-280.

Bamford, J., \& Day, R. R. (Eds.). (2004). Extensive reading activities for language teaching. New York: Cambridge University Press. 
Barkhuizen, G., Benson, P., \& Chik, A. (2014). Narrative inquiry in Language teaching and learning research. Abingdon, UK: Routledge.

Bialystok, E. (1983). Some factors in the selection and implementation of communication strategies. In C. K. Faerch, Strategies in interlanguage communication (pp. 100-118). London: Longman.

Bidabadi, F. S., \& Yamat, H. (2014). Strategies employed by Iranian EFL freshman university students in extensive listening: a qualitative research. International Journal of Qualitative Studies in Education (QSE), 27(July 2014). https://doi.org/10.1080/09518398.2012.737042

Boekaerts, P. R. Pintrich, \& M. Zeidner (Eds.), Handbook of self-regulation. San Diego, CA: Elsevier Academic Press.

Cheng, H. and Dörnyei, Z. (2007). The Use of Motivational Strategies in Language Instruction: The Case of EFL Teaching in Taiwan. Innovation in Language Learning and Teaching, 1, 153-174. http://dx.doi.org/10.2167/illt048.0

Corno, L. and R. Kanfer. 1993. 'The role of volition in learning and performance' in L. Darling-Hammond (ed.): Review of Research in Education. Peacock Publishers

Dörnyei, Z. (2001). Motivational strategies in the language classroom. Cambridge: Cambridge University Press.

Dörnyei, Z. (2005). The psychology of the language learner: Individual differences in second language acquisition. Mahwah, NJ: Lawrence Erlbaum.

Dornyei, Zoltan and Otto, Istvan (1998). Motivation in action: A process model of L2 motivation. In: Working Papers in Applied Linguistics, Vol. 4.

Gagen-Lanning, K. (2015). The Effects of Metacognitive Strategy Training on ESL Learners' Self-Directed use of TED Talk Videos for Second Language Listening. Unpublished master's thesis, lowa State University Ames, lowa.

Gao, X. (2007). Has language learning strategy research come to an end? A response to Tseng et al. (2006). Applied Linguistics, 28(4), 615-620. doi: 10.1093/applin/amm034

Goh, C. (2002). Exploring listening comprehension tactics and their interaction patterns. 30 (2), 85-206

Hung-chun Wang \& Cheryl Wei-yu Chen (2019): Learning English from YouTubers: English L2 learners' self-regulated language learning on YouTube, Innovation in Language Learning and Teaching, DOI: 10.1080/17501229.2019.1607356

Kirmizi, O. (2014). Self-regulated Learning Strategies Employed by Regular, Evening, and Distance Education English Language and Literature Students. The Anthropologist, 18(2), 447-460.doi:10.1080/09720073.2014.11891563

Krashen, S.D., (1985). The Input Hypothesis: Issues and Implications. London: Longman. Listeners: A descriptive study. Foreign Language Annals, 30: 387409.

Kuhl, J. (1987). 'Action control: The maintenance of motivational states' in F. Halisch and J. Kuhl (eds): Motivation, Intention and Volition. Springer. 
Lemos, M. S. (1999). Students' goals and self-regulation in the classroom. International Journal of Educational Research, 31, 471-485.

Mothlaka, H. (2012). Developing ESL listening: Promoting student motivation. (Magister thesis).

Nation, I. S. P., \& Newton, J. (2008). Teaching ESL/EFL listening and speaking. New York, NY: Routledge.

Nunan D. (1997). Listening in Language Learning. The Language Teacher. The Japan Association of Language Learning. Vol. 21 No.9, pp 47-51.

Pintrich, P. R. (2000). The role of goal orientation in self-regulated learning.

Renandya, W. A., \& Farrell, T. S. C. (2011). Teacher the tape is too fast: Extensive listening in ELT. ELT Journal, 65 (1), 52-59.

Rose, H. \& Harbon, L. (2013). Self-Regulation in Second Language Learning: An Investigation of the Kanji-Learning Task. 46 (1), 96-107

Rost, M. (1994). Introducing Listening. London: Penguin books.

Safdari, S., \& Maftoon, P. (2016). EFL Learners' Deployment of Motivational SelfRegulatory Strategies and their Academic Achievement.

Şahin Kizil, AŞ, and Z. Savran. (2016). Self-regulated Learning in the Digital age: An EFL Perspective. Novitas-ROYAL (Research on Youth and Language) 10: 147158

Shyr, W.-J., and C.-H. Chen. (2018). Designing a Technology-Enhanced Flipped Learning System to Facilitate Students' Self-Regulation and Performance. Journal of Computer Assisted Learning 34: 53-62.

Skehan, P. (1989). Individual differences in second language learning. London: Edward Arnold.

Stevick, E. W. (1990). Research on what? Some terminology. Modern Language Journal, 74(2), 143153. doi: 10.1111/j.1540-4781.1990.tb02560.x

Vandergrift, L., 1997. The strategies of second language (French) listeners. Foreign Language annals, 30 (3), 387-409.

Widodo, H. P., \& Rozak, R. R. (2016). Engaging student teachers in collaborative and reflective online video-assisted extensive listening in an Indonesian initial teacher education (ITE) context. Electronic Journal of Foreign Language Teaching, 13(2), 229-244.

Zheng, C., J.-C. Liang, Y.-F. Yang, and C.-C. Tsai. (2016). The Relationship between Chinese University Students' Conceptions of Language Learning and Their Online Self-Regulation. System 57: 66-78.

Zimmerman, B. J. (2002). Becoming a Self-Regulated Learner: An Overview. Theory into Practice, 41, 64-70. http://dx.doi.org/10.1207/s15430421tip4102 2. 